\title{
Janet Holmes and the Language in the Workplace Project: Exploring the foundations of modern views and research paths in sociolinguistics ${ }^{1}$
}

\author{
Mariana Lazzaro Salazar*
}

Janet Holmes is Emeritus Professor in Linguistics at Victoria University of Wellington in New Zealand and a Fellow of the Royal Society of New Zealand. She is an Honorary Professor at the University of Warwick (2010-2016) and in 2010 she was awarded an Honorary Doctorate by Uppsala University, Sweden. She is Associate Director of the Wellington Language in the Workplace project and she was also Director of the project which produced the Wellington Corpus of Spoken New Zealand English. She has published on a range of sociolinguistic and pragmatics topics, including New Zealand English, sexist language, pragmatic particles and hedges, compliments, apologies, disagreement, humour and small talk. Her publications include a textbook: An Introduction to Sociolinguistics, a book of readings: Sociolinguistics, co-edited with John Pride, New Zealand Ways of Speaking English, co-edited with Allan Bell, and several books on language and gender, including Leadership, Discourse and Ethnicity, Gendered Talk at Work, Women, Men and Politeness, and the Blackwell Handbook of Language and Gender.

What'syourperception of the evolution of the field of sociolinguistics since when you started developing research in this area of inquiry? - Sociolinguistics has become very much more dynamic in every area. Researchers are using social constructionist theories and investigating how social actors construct their identities through their language choices as an on-going process. People constantly adjust the way they present themselves according to what they perceive are the expectations

\footnotetext{
${ }^{1}$ This interview was conducted during the 9th International Gender and Language Association Conference (Igala), at the City University of Hong Kong, 20th May 2016. Post-doctoral Fellow (Fondecyt Postdoctoral No 3160104, Conicyt) Communication and Interculturality in Public Healthcare Settings in Chile.

* Vicerrectoría de Investigación y Posgrado, Universidad Católica del Maule. Curicó, Chile. Email:mlazzaro@ucm.cl
} 
of others, for instance, and maybe during the process of an interaction that may change. So it's a constantly dynamic, changing perception of how language is used, which wasn't the case when sociolinguistics first developed in the 1970s. Sociolinguistics back then was much more static. A good example would be the sort of studies that William Labov did. Adopting a sociological classification, he used social class as a basic category and correlated people's language with their social backgrounds in a very useful way, which is still a very useful starting point for any social dialect survey. Progressively, however, researchers have realized that language is much more dynamic and that people shift quite dramatically in different situations, that they could get involved in crossings, by borrowing ethnic identity markers from other groups for humour, for annoying somebody, insulting them, or just simply to enrich the communication patterns and processes they are involved in. Language is seen as a negotiation process rather than a fixed set of patterns that we draw on in a particular situation.

What theories do you draw on to explain sociolinguistic phenomena? - One of the most influential ones until very recently has been domain theory, which involved the notion that the features of the situation such as the physical setting, the typical participants and the sort of topics that one might discuss in particular settings play a vital role in how we communicate; we learn how to speak appropriately in different contexts. Joshua Fishman identified five different domains, which are quite useful starting points for looking at language choice in both monolingual and multilingual societies. But of course, within those domains we find that people actually code switch so we need a more fine-grained theory to deal with that - so Interactional Sociolinguistics developed by John Gumperz has probably been the most influential in recent sociolinguistic research, looking at what values and attitudes and identities are associated with the use of one language rather than another. How people know the norms but switch between languages or integrate them in different contexts is a really interesting area of study, paying close attention to cross-cultural difference and misunderstandings. So sociolinguists have an important role to play I think in unpacking the presuppositions we bring to a situation and showing some of the inferences we make about language from the pragmatic aspects of analysis.

You founded the Language in the Workplace Project. Can you describe what the project is about? - Before the LWP [Language in the Workplace Project], Alan Bell and I and Mary Boyce had been involved in the social dialect project which had been funded by the Social Science Research Council in New Zealand. But sadly with government priorities there was no way we were gonna get more money to study New Zealand English, which was what we were 
interested in. That's when I began to think about ways in which to make a bigger impact, something that would have value in the real world from other people's point of view. I had no doubt that what we did in terms of social dialectology was valuable, but it wasn't apparent to people in the real world that that was a worthwhile use of an academic's time. So I thought 'well nobody has looked at how New Zealand English is used in different domains' and the most obvious one from my point of view was the workplace, because that's where we spend most of our time. It was really thinking about how we might get some funding to help us provide scholarships and research assistants' jobs and get involved in a topic area, a project that would actually have some value. So I put in an application to what was then the Foundation for Research, Science and Technology and they were very interested in something that involved employment and so that was the beginning of the project. And we began in quite a very small way with Maria Stubbe, Bernadette Vine and I. I approached one of my friends who worked in a Government Ministry and who vouched for me as reliable and trustworthy to get me an interview with the CEO [Chief Executive Officer] who was very interested in what we were doing. She asked me to give a talk on language and gender to the ministry people, and at the end of that talk I said 'well you know what we really want to do is look at the way you talk to each other at work', and they said 'oh that's really interesting! Can you start next week?' and we went 'oh my God!' [laughs]. We had no preparation, and no equipment. I said 'well maybe you could give us a month' [laughs]. And we had to get our act together very fast and we did. The LWP is a very big now. It's grown and grown and we've got over 30 workplaces where we've collected data and over two million words in our corpus of workplace discourse and hundreds of participants. There are many workplaces now who would be happy to have us work there, but we're trying to keep our focus on areas that are useful to government policy and, in particular, employability. So our latest focus is on the hospitality industry and we're looking at the way people operate front-stage and back-stage in restaurants. So looking at the way in which particularly overseas people coming to New Zealand, tourists and so on, are spoken to and looked after, or not!, in restaurants. So that's the direction we're going next. It's looking at possible sources of misunderstanding between overseas people and New Zealanders. Because New Zealanders take for granted a lot of background knowledge without realizing that people who come from overseas are unfamiliar with the things they assume. Often people are offended because New Zealanders are very informal and use humour a lot, and people from overseas don't understand that the ways of doing things in New Zealand workplaces are often very different. 
One of the topic areas you have mostly focused on is language and gender. What has been your main interest in that area? - My own interest has been in the area of leadership so I've been looking at ways in which competent, capable women leaders present themselves, how they manage the requirements of their role, how they perceive themselves, and the differences between their perceptions and the way they actually operate in workplaces. One of the interesting things we found is that for both, men and women leaders, their narratives, the 'hero' stories, very often are very different from the ways in which they actually behave in the workplace. There's a Māori guy, for example, who sounds very authoritarian, decisive, very strict and cut-throat in the intervie, and he's very different in meetings. He's informal, humorous, very considerate of other people, makes fun of them sometimes, but in a very informal chatty sort of style, and switches when he needs to into a more decisive mode. So those sorts of differences between how people present themselves in one context and another are classic sociolinguistics.

\section{If you had the chance to do research in the Chilean context, what would} you like to explore in that context? - I am impressed by the extent to which a number of scholars in Chile have already been looking at discourse of diversity in different contexts, such as mining workers. These are very innovative and interesting areas to be working in. There wasn't anything that I could find immediately in the literature on just the sort of research that I'm most familiar with, which is professional workplaces. I think there's always an advantage in starting off with an area where you have some familiarity with the norms, avoiding situations that are just so unfamiliar that you're going to put your foot in it every time you open your mouth. So I would see workplace discourse as a possible area of study, in particular meetings because they have a structure, but you can also get quite a lot of diversity. I was struck by your research where you showed how transactionally-oriented certain meetings are because there's a time constraint and we've got evidence too of a more relaxed workplace where the time constraint doesn't seem to be pressured, and there's a lot of social talk and digressions. It's interesting to look at how people manage that and to see other people's reactions because workplace cultures aren't necessarily homogenous. There will be some people who are comfortable with a particular style and others not. We've done work in factories and the most familiar example is the one where this Samoan woman, who is the director of a particular workplace team, is very witty, acute and can give insults back to the members of her team who are just as happy to swear at her and insult her. Obviously the newcomer to that team might be taken aback a bit but in the long run they might appreciate that it was part of what it means to be a member of that community of practice. 
In your opinion, what is the value of interdisciplinary collaboration in sociolinguistic research? - I'm very keen on it because we've always found it very fruitful. In the applied linguistics area, we've collaborated with Nicky Riddiford, who runs the professional communication skills course for professional migrants. She has made very great use of our work in turning it into teaching materials for students who come to New Zealand, and who are very skilled at their jobs, and their English is very good but they just don't know the socio-pragmatic norms. We also collected data in eldercare establishments and building sites and the Ministry of Business Innovation and Employment [MBIE] has found that particularly useful because a lot of refugees who come to New Zealand move into elder care as a stepping stone often to nursing or building sites as an obvious place to get jobs. So our data is often turned into teaching resources which have been put on the MBIE's website. That sort of interdisciplinary collaboration has been particularly fruitful. 